\title{
RAHASIA MULTIPLE INTELLIGENCE PADA ANAK
}

\author{
Juli Astuti \\ (juliaok@ymail.com) \\ Dosen Sekolah Tinggi Ilmu Tarbiyah (STIT) Islamic Village Tangerang
}

\begin{abstract}
Abstrak: In educational institutions, parents, teachers and the public often assume that intelligence can only be seen through academic scores and formal test results such as getting a high score or being ranked in a class. This conception is outdated and superficial. In this era of globalization where educational practitioners are exploring the concept of Multiple Intelligences. Multiple Intellegences as a broad concept of intelligence and has undergone several changes due to the emergence of the theory of multiple intelligences proposed by a psychologist from Harvard University. Intelligence is not limited to formal tests, it's a multidimensional and one's discovery process of competence. Multiple Intellegences is a theory of intelligence pioneered by a psychologist from Harvard University who shows that everyone is intelligent and tends to have intelligence among the ten dimensions of intelligence. In Islam (al Qur'an) multiple intelligences is actually already put forward various developments about intelligence and various human potential. There are ten dimensions of intelligence put forward by Hardward Gardner namely linguistic intelligence, logical-mathematical intelligence, visual-spatial intelligence, kinesthetic-physical-kinesthetic, musical intelligence, interpersonal intelligence, intrapersonal intelligence, naturalistic, existential and emotional intelligence.
\end{abstract}

Kata Kunci: Multiple Intellegences

\section{A. Pendahuluan}

Allah Swt, menciptakan manusia pada dasarnya memiliki keunikan, dan tingkatan kecerdasan yang berbeda-beda. Tidak seorang pun manusia di dunia ini yang diciptakan sama, meski kembar sekali pun. Kecerdasan merupakan salah satu anugerah yang terbesar dari Allah Swt kepada manusia dan menjadikannya sebagai salah satu kelebihan manusia dibandingkan dengan makhluk lainnya. Secara fisik, manusia memiliki struktur tubuh yang sangat sempurna, dan manusiapun diberikan akal pikiran yang tidak dimiliki oleh makhluk lainnya, oleh karena itu manusia adalah makhluk jasadiyah dan ruhaniyah. Makhluk ciptaan Allah yang paling sempurna adalah manusia, terdapat pada (Q.S.At-Tin: 5). Allah memberikan anugrah kepada manusia berupa akal pikiran, agar digunakan untuk mengatur dan mengerahkan segala sesuatu. Berbagai potensi dan kecerdasan yang dimiliki manusia wajib digali, dikembangkan dan diarahkan dengan baik. Dengan kecerdasannya, manusia dapat terus menerus mempertahankan dan meningkatkan 
ISTIGHNA, Vol. 1, No 2, Juli 2018 P-ISSN 1979-2824

Homepage: http://e-journal.stit-islamic-village.ac.id/index.php/istighna

Juli Astuti

Rahasia Multiple Intelligence Pada Anak

kualitas hidupnya yang semakin kompleks, melalui proses berfikir dan belajar secara terus menerus. Banyak orang meyakini bahwa orang yang cerdas adalah orang yang memiliki kemampuan Intelligence Quotient (IQ) yang tinggi, namun pada kenyataannya, tidak semua orang yang memiliki kemampuan IQ yang tinggi itu dapat memiliki kemampuan adaptasi, sosialisi, pengendalian emosi, dan kemampuan spiritual. Banyak orang yang memiliki kecerdasan IQ, namun ia tidak memiliki kemampuan untuk bergaul, bersosialisasi dan membangun komunikasi yang baik dengan orang lain. Banyak juga orang yang memiliki kemampuan IQ, tapi ia tidak memiliki kecerdasan dalam melakukan hal-hal yang dapat menentukan kebehasilannya di masa depan, prioritas - prioritas apa yang mesti dilakukan untuk menuju sukses dirinya. Masih ada orang tua dan sistem sekolah yang memaksakan anak untuk belajar di bidang yang tidak disukai anak yang akan menjadi kelemahannya. Pada tahun 2004, tes IQ menjadi tren di sekolah dasar, dan ramai-ramai menyeleksi anak-anak yang hendak masuk sekolah dengan menggunakan tes IQ untuk meningkatkan "gengsi”,. Mereka beranggapan bahwa sekolah yang baik adalah jika para siswanya pintar-pintar, dan siswa yang pintar itu dilihat dari IQ-nya di atas rata-rata. Oleh karena itulah mereka menyelenggarakan tes IQ. Meskipun sebenarnya mereka kurang begitu memahami kerangka landasan teoretis dan filosofisnya; untuk apa tes IQ itu, apa kelemahan dan kelebihannya, dan kapan semestinya hal itu dilakukan. ${ }^{41}$ Pada awalnya, dikenal bahwa kecerdasan seseorang adalah mereka yang memilki kualitas IQ yang sangat tinggi, hal demikian tidaklah salah karena pada awal sejarah perkembangannya, untuk mengetahui tingkat kecerdasan seseorang adalah dengan mengetahui IQ-nya. Orang yang pertama kali berpikir mengenai mungkinnya dilakukan pengukuran intelegensi atau kecerdasan adalah Galton, sepupu Darwin. Hal yang mendorongnya untuk memiliki pemikiran demikian adalah karena Galton tertarik pada perbedaan-perbedaan individual dan pada hubungan antara hereditas dan kemampuan mental. Menurut Galton ada dua kualitas umum yang dapat membedakan antara orang yang lebih cerdas (more intelligent) dari orang yang kurang cerdas (less intelligent) yaitu energi dan

\footnotetext{
${ }^{41}$ Agus Efendi, Revolusi Kecerdasan Abad 21, (Bandung, Alfabeta, 2005), Cet. I, h. 58
} 
ISTIGHNA, Vol. 1, No 2, Juli 2018 P-ISSN 1979-2824

Homepage: http://e-journal.stit-islamic-village.ac.id/index.php/istighna

Juli Astuti

Rahasia Multiple Intelligence Pada Anak

sensitivitas. Menurutnya, orang cerdas itu memiliki tingkat energi yang istimewa dan sensitivitas terhadap rangsangan di sekitarnya. Pada tayangan acara Kick Andy, "Yohanes Surya membuktikan bahwa tidak ada anak yang bodoh, yang ada adalah mereka belum menemukan guru terbaik dan metode yang tepat". ${ }^{4}$ Ternyata masih ada kejadian yang kita dengar dari orang tua atau guru mengatakan, "bahwa anak ini bodoh", namun ketika kita menanyakan lagi dari jenis apa kebodohan anak itu? Jawabannya mereka, hanya dari memiliki nilai sangat rendah dalam pelajaran, sedangkan anak yang memiliki nilai tinggi pada pelajaran, namun lemah dalam berprilaku sosial dan emosionalnya, malah mereka tetap dianggap sebagai anak yang pintar.

Howard Gardner yang dengan sangat serius mempelajarinya, dan ia sampai pada suatu kesimpulan bahwa kecerdasan manusia itu tidak tunggal, tapi majemuk, bahkan tak terbatas. Belakangan teori kecerdasan Howard Gardner ini dikenal dengan Multiple Intelligence (Kecerdasan Majemuk) Linguistic Intelligence (Kecerdasan Bahasa), Logic-Mathematical Intelligence (Kecerdasan Logis-Matematis), Visual-Spatial Intelligence (Kecerdasan VisualSpasial), Bodily-Kinesthetic Intelligence (Kecerdasan Kinestetik), Musical Intelligence (Kecerdasan Musik), Interpersonal Intelligence (Kescerdasan Antarpribadi), Intrapersonal Intelligence (Kecerdasan Intrapesonal), dan Natural Intelligence (Kecerdasan Natural), kecerdasan Eksistensial dan kecerdasan emosional. ${ }^{43}$ Dengan sepuluh kecerdasan ini, orang tua memiliki alat atau cara untuk mengembangkan kecerdasan anak - anaknya. Namun demikian, dengan pengembangan sepuluh model kecerdasan ini hanya di pergunakan sebagai alat bantu dalam mengoptimalkan semua potensi di setiap area kecerdasan. Dalam membuktikan bahwa setiap anak memiliki kecerdasan yang berbeda yakni mencermati populasi khusus lain, orang - orang yang luar biasa, orang yang amat cerdas dalam bidang tertentu tetapi nyaris tidak memahami bidang lain, anak anak yang tidak mampu belajar, semua yang menunjukkan profil pemahaman dengan perbedaan yang tajam. Sehingga dalam multiple Intelligences ada dua 2015) hlm.7

${ }^{42}$ Alamsyah Said, Strategi Mengajar Multiple Intellegences,(Jakarta Prenadamedia Grup

${ }^{43}$ Fred luthans, Perilaku Organisasi edisi 10 (Jogyakarta copy right, 2006),hlm.330 
ISTIGHNA, Vol. 1, No 2, Juli 2018 P-ISSN 1979-2824

Homepage: http://e-journal.stit-islamic-village.ac.id/index.php/istighna

Juli Astuti

Rahasia Multiple Intelligence Pada Anak

asumsi dasar berkaitan dengan penelitian. Asumsi pertama adalah bahwa tidak semua orang mempunyai minat dan kemampuan yang sama, tidak semua anak anak belajar dengan cara yang sama. Asumsi kedua adalah sesuatu yang menyakitkan itu adalah asumsi bahwa sekarang tidak seorang yang dapat belajar segala sesuatu yang ingin dipelajarinya. ${ }^{44}$

Pengembangan kecerdasan majemuk anak hendak dilakukan sejak dini, minimal sejak usia sekolah dasar. Pendidikan harus dapat memberikan kesempatan kepada anak untuk mencapai potensi tertingginya, baik dalam bidang kognitif, emosional dan kemampiuan kreatif. Bagaimana Islam memandang sepuluh model kecerdasan tersebut, berikut komporasi teori Howard Gardner dengan teori pendidikan anak yang dilakukan oleh Rasul.

\section{B. Multipel Intelligences}

Multipel Intelligence itu sebenarnya sudah ada sejak jaman Rasullullah Saw, hanya saja baru dicetuskan oleh Howerd Gardner seorang professor dari Harvard University, sejak tahun 1970-an, tetapi baru pada tahun 1983 melalui bukunya Frames of mind, Howerd Gardner benar-benar memunculkan teorinya tersebut. Pada tahun 1993 ia mempublikasikan bukunya berjudul Multiple Intelligences, setelah melakukan banyak penelitian tentang implikasi teori inteligensi ganda di dunia pendidikan. Dalam penelitiannya Gardner menemukan bahwa meskipun peserta didik hanya menonjol pada beberapa intelegensi, mereka dapat dibantu lewat pendidikan dan bantuan pendidikan untuk mengembangkan intelegensi yang lain, sehingga dapat di gunakan dalam mengembangkan hidup lebih menyeluruh. ${ }^{45}$

Intelligence menurut Howard Gardner adalah pengetahuan atau kemampuan untuk mengemas suatu produk atau menggunakan suatu keterampilan dalam cara yang dihargai oleh budaya dimana anda hidup. ${ }^{46}$ Kecerdasan dalam pengertian yang lain, merupakan kemampuan untuk menyelesaikan masalah atau

\footnotetext{
${ }^{44}$ Howard Gardner, Multipel Intelligences ; Kecerdasan Majemuk Teori dan Praktek, penerjemah Alexandra sindoru, (Batam: Interaksara, 2003 ), h. 34.

${ }^{45}$ Paul Suparno, Teori Inteligensi ganda dan aplikasinya di sekolah, (Yogyakarta;Kanisus, 2004) cet. 1 h. 12

${ }^{46}$ Eric Jensen, Memperkaya otak; Cara Memaksimalkan Potensi Setiap Pembelajar,( Jakarta; Indeks, 2008). H. 25
} 
ISTIGHNA, Vol. 1, No 2, Juli 2018 P-ISSN 1979-2824

Homepage: http://e-journal.stit-islamic-village.ac.id/index.php/istighna

Juli Astuti

Rahasia Multiple Intelligence Pada Anak

menggunakan ide, produk atau kemampuan dalam suatu cara yang di nilai oleh satu atau lebih kebudayaan. ${ }^{47}$ Setiap kecerdasan didasarkan pada potensi biologis, yang kemudian diekspresikan sebagai hasil dari faktor-faktor genetic dan lingkungan yang saling mempengaruhi.

Rasulullah Saw, mendefinisikan kecerdasan dengan menggunakan kata alkayyis, sebagaimana dalam hadits berikut :

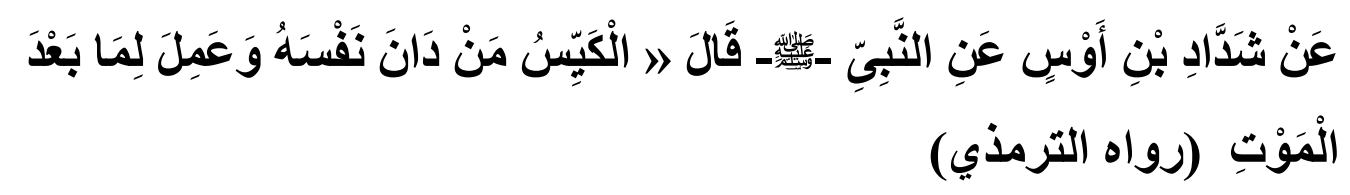

Artinya: "Dari Syaddad Ibn Aus, dari Rasulullah Saw. Bersabda: orang yang cerdas adalah orang yang merendahkan dirinya dan beramal untuk persiapan sesudah mati (H.R. At-Tirmidzi)".

Pada dasarnya, setiap manusia terlahir dengan potensi inteligensinya masing-masing sebagai anugerah dari Allah. Persoalannya, justru terletak pada bagaimana cara mengembangkan potensi inteligensi yang beragam tersebut, ${ }^{48}$ karena inteligensi telah ada dan mengakar dalam saraf manusia, terutama dalam otak yang merupakan pusat seluruh aktivitas manusia. Konsep Islam mengenai inteligensi, telah secara jelas disebutkan dalam surat al-Isra' ayat 70.

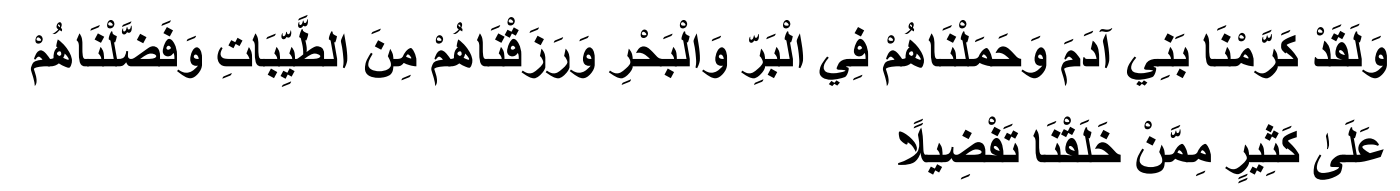

Artinya: Dan Sesungguhnya telah Kami muliakan anak-anak Adam, Kami angkut mereka di daratan dan di lautan, Kami beri mereka rezki dari yang baikbaik dan Kami lebihkan mereka dengan kelebihan yang sempurna atas kebanyakan makhluk yang telah Kami ciptakan. Pepatah Arab mengatakan:

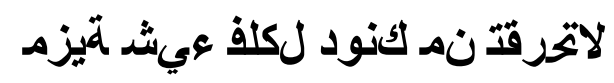

${ }^{47}$ Ibid .h. 25

${ }^{48}$ Arief Rachman, "Genius Learning Strategy" dalam Adi W. Gunawan, Genius Learning Strategy: Petunjuk Praktis untuk Menerapkan Accelerated Learning, (Jakarta: PT. Gramedia Pustaka Utama, 2006), hlm. xiii. 
ISTIGHNA, Vol. 1, No 2, Juli 2018 P-ISSN 1979-2824

Homepage: http://e-journal.stit-islamic-village.ac.id/index.php/istighna

Juli Astuti

Rahasia Multiple Intelligence Pada Anak

Artinya: Jangan kau anggap sepele segala sesuatu yang lebih rendah darimu karena segala sesuatu pasti ada kelebihannya ${ }^{49}$

Ayat dan pepatah ini mengindikasikan adanya potensi superiority dalam diri setiap manusia. Dengan inteligensinya, manusia dapat mempertahankan dan meningkatkan kualitas hidupnya yang semakin kompleks melalui proses berpikir dan belajar secara terus menerus, melalui pendidikan.

Menurut Gardner : "Multiple intelligence is a natural way to structure learning. All the aspects of the person are taught to, meaning can be extracted, and applications can be made to life. The childern in our classrooms are multifaceted and have many abilities". 50 Yang artinya: " Kecerdasan ganda adalah cara dasar pada pembelajaran struktur. Semua aspek-aspek manusia telah dipelajari juga, arti dapat dikutip dan penerapan dapat dibuat untuk hidup. Peserta didik di kelas beranekaragam segi dan memiliki banyak kemampuan”.

Kecerdasan majemuk perspektif Munif Chatib adalah kemampuan seseorang dalam membiasakan dirinya dengan bergerak membuat produk-produk atau karya- karya baru yang mempunyai nilai budaya yang tinggi dan mampu menyelesaikan masalah yang dihadapi secara mandiri serta menemukan kondisi akhir terbaiknya dengan cepat dan baik. ${ }^{51}$

Jadi multiple intelligences adalah suatu kesadaran yang dilakukan para pendidik dalam mengembangkan pendidikan dengan cara memperlakukan semua peserta didik dengan perlakuan yang sama dan istimewa.

Menurut Gardner, kecerdasan itu tidak hanya diartikan sebagai IQ semata, namun kecerdasan itu menyangkut kemampuan seseorang untuk memecahkan dan menyelesaikan masalah serta menghasilkan produk atau ide. ${ }^{52}$ Gardner menyatakan bahwa kecerdasan itu tidak sepenuhnya genetic dan tetap sejak lahir

\footnotetext{
${ }^{49}$ Syaikh Muhammad Nawawi bin Umar al Jawiy, Syarh Nashaihul 'Ibad, (Surabaya: Darul 'Abidin, tth), hlm. 9.

${ }^{50} \mathrm{http}$ : //www.mitest.com/omultint.htm.

51 Munif Chatib, Sekolahnya Manusia Sekolah Berbasis Multiple Intelligences (Bandung: Kaifa, 2015), hlm. 65

${ }^{52}$ Howard Gardner, Multiple Intelligences: Kecerdasan Majemuk Teori dan Praktek, penerjemah Alexander Sindoru, (Batam: Interaksara, 2003), hlm. 34.
} 
ISTIGHNA, Vol. 1, No 2, Juli 2018 P-ISSN 1979-2824

Homepage: http://e-journal.stit-islamic-village.ac.id/index.php/istighna

Juli Astuti

Rahasia Multiple Intelligence Pada Anak

namun kecerdasan dapat dipelajari dan di kembangkan. ${ }^{53}$ Hampir semua aktivitas dalam bidang kehidupan memerlukan kombinasi kecerdasan, contohnya untuk menjadi pemain bola yang handal, seorang harus memiliki kecerdasan kinestetik dan interpersonal yang tinggi. Demikian juga untuk menjadi seorang pemain piano, seseorang perlu memiliki kecerdasan music, kecerdasan kinestetik dan interpersonal yang tinggi.

Multipel intellegences memiliki karakteristik konsep sebagai berikut $:^{.54}$

1. Semua intelegensi itu berbeda-beda, tetapi semuanya sederajat. Dalam pengertian ini tidak ada intelegensi yang lebih baik atau lebih penting dari intelegensi yang lain (Gardner, 1993; Hine, 2003; Armstrong, 1996)

2. Kecerdasan dimiliki manusia dalam kadar yang tidak persis sama. Semua kecerdasan dapat dieksplorasi, ditumbuhkan, dan dikembangkan secara optimal.

3. Terdapat banyak indikator kecerdasan dalam tiap-tiap kecerdasan. Dengan latihan, seseorang dapat membangun kekuatan kecerdasan yang dimiliki dan menipiskan kelemahan-kelemahan.

4. Semua kecerdasan yang berbeda tersebut bekerja sama untuk mewujudkan aktivitas yang diperbuat manusia. Satu kegiatan mungkin memerlukan lebih dari satu kecerdasan, dan satu kecerdasan dapat digunakan dalam berbagai bidang ( Gardner, 1993)

5. Semua jenis kecerdasan tersebut ditemukan diseluruh atau semua lintas kebudayaan di seluruh dunia dan kelompok usia (Gardner, 1993; Armstrong, 2004)

6. Tahap-tahap alami dari kecerdasan dimulai dengan kemampuan membuat pola dasar. Musik, misalnya, di tandai dengan kemammpuan membedakan tinggi rendahnya nada. Sementara spasial dimulai dengan kemampuan pengaturan dimensi.

7. Saat seseorang dewasa, kecerdasan diekspresikan melalui rentang pencapaian profesi dan hobi. Kecerdasan logika matematika yang

\footnotetext{
${ }^{53}$ Fred luthans, Perilaku Organisasi edisi 10 (Jogyakarta copy right, 2006),hlm.330

${ }^{54}$ Tadkiroatun Musfiroh, Cerdas Melalui bermain (cara mengasah Multipel Intellegence anak), (Jakarta, Grasindo 2008)hlm.37
} 
ISTIGHNA, Vol. 1, No 2, Juli 2018 P-ISSN 1979-2824

Homepage: http://e-journal.stit-islamic-village.ac.id/index.php/istighna

Juli Astuti

Rahasia Multiple Intelligence Pada Anak

dimulai sebagai kemampuan pola pada masa balita dan berkembang menjadi penguasaan simbolik pada masa anak-anak, misalnya akhirnya mencapai kematangan ekspresi dalam wujud profesi sebagai ahli matematika, akuntan dan ilmuan.

8. Ada kemungkinan seorang anak berada pada kondisi "beresiko", mereka akan mengalami kegagalan dalam tugas tugas tertentu yang melibatkan kecerdasan tersebut apabila tidak memperoleh bantuan khusus dari orang dewasa (Gardner, 1993).

Esensi teori Multipel Intellegences (kecerdasan majemuk) adalah menghargai keunikan setiap orang, berbagai variasi cara belajar mewujudkan sejumlah model untuk menilai mereka, dan cara yang hampir tak terbatas untuk mengaktualisasikan diri di dunia ini (Howard Gardner dalam Armstrong 1994). ${ }^{55}$ Gardner telah menetapkan sepuluh kecerdasan yang terbaru yaitu Verballinguistik, Logis-matematis, Visual-spasial, Kinestetik-jasmani, Musikal, Interpersonal, Intrapersonal, Naturalis, Spiritual- Eksistensial dan Emosional.

Tabel 1.1 Multiple Intelligence dari Gardner

Sumber: Diadaptasi dari Lou Russell, The Accelerated Learning Fieldbook, Jossey-Bass/Pfeiffer, San Francisco, 1999, hlm 60-70

\begin{tabular}{|c|l|l|c|}
\hline No & Kecerdasan Awal & \multicolumn{1}{|c|}{ Karakteristik } & Contoh terkenal \\
\hline 1. & $\begin{array}{l}\text { Logika/ } \\
\text { Matematika }\end{array}$ & $\begin{array}{l}\text { Memproses secara analitis, } \\
\text { mengkalkulasi, mengukur. }\end{array}$ & $\begin{array}{c}\text { Ilmuan Albert } \\
\text { Einstein }\end{array}$ \\
\hline 2 & Verbal/ Linguistik & $\begin{array}{l}\text { Berpikir melalui kata, } \\
\text { menggunakan kata untuk } \\
\text { pembelajaran }\end{array}$ & $\begin{array}{c}\text { Konsultan Tom } \\
\text { peters }\end{array}$ \\
\hline 3 & Interpersonal & $\begin{array}{l}\text { Memahami orang lain, } \\
\text { berproses melalui interaksi, } \\
\text { berimpati humor. }\end{array}$ & $\begin{array}{c}\text { Entertainer Operah } \\
\text { Winfrey }\end{array}$ \\
\hline 4 & Intrapersonal & $\begin{array}{l}\text { Berpikir dalam keheningan, } \\
\text { suka menyendiri, berorientasi } \\
\text { pada tujuan, independen, } \\
\text { bertekun }\end{array}$ & $\begin{array}{c}\text { Bisnisman Tycoon } \\
\text { Howard Hughes }\end{array}$ \\
\hline 5 & Visual/ spasial & $\begin{array}{l}\text { Menggunakan model mental, } \\
\text { berpikir secara tiga dimensi, } \\
\text { menggambarkan bagaimana }\end{array}$ & Arsitek Frank \\
Lioyd Wright
\end{tabular}

${ }^{55}$ Tadkiroatun Musfiroh, Cerdas Melalui bermain (cara mengasah Multipel Intellegence anak), (Jakarta, Grasindo 2008)hlm.38 
ISTIGHNA, Vol. 1, No 2, Juli 2018 P-ISSN 1979-2824

Homepage: http://e-journal.stit-islamic-village.ac.id/index.php/istighna

Juli Astuti

Rahasia Multiple Intelligence Pada Anak

\begin{tabular}{|c|l|l|c|}
\hline & & $\begin{array}{l}\text { memperoleh tempat atau } \\
\text { memecahkan masalah. }\end{array}$ & \\
\hline 6 & Musik & $\begin{array}{l}\text { Sensitif pada pola nada, melodi, } \\
\text { irama, ada pada pemain dan } \\
\text { pendengar }\end{array}$ & $\begin{array}{c}\text { Komposer } \\
\text { Wolfgang Mozart }\end{array}$ \\
\hline 7 & Fisik / Kinestetik & $\begin{array}{l}\text { Gerakan fisik, termasuk seluruh } \\
\text { tubuh berproses dengan } \\
\text { meloncat atau menari }\end{array}$ & $\begin{array}{c}\text { Pemain Basket } \\
\text { Michael Jordan }\end{array}$ \\
\hline 8 & Naturalis & $\begin{array}{l}\text { Perlu pertahanan alami, } \\
\text { kekuatan dalam kategorisasi } \\
\text { alami atau dunia urban }\end{array}$ & $\begin{array}{c}\text { Penyanyi John } \\
\text { Denver }\end{array}$ \\
\hline 10 & Eksistensial & $\begin{array}{l}\text { Bukan agama, tahu mengapa } \\
\text { mereka berada di sini, misi } \\
\text { pribadi. }\end{array}$ & $\begin{array}{c}\text { Pemimpin Hak } \\
\text { Asasi Manusia } \\
\text { Martin Luther } \\
\text { King }\end{array}$ \\
\hline
\end{tabular}

Membahas kecerdasan menurut pendekatan Gadner, ketiga kriteria berikut ini harus di penuhi : 1) dapat diukur, 2) dinilai menurut budaya seseorang, dan 3) tingkat kegagalan seseorang saat ditantang untuk kratif atau memecahkan masalah. Gardner menunjukkan bahwa kecerdasan yang diidentifikasinya adalah: 1) jenis konstruksi baru dan sebaiknya tidak dikacaukan dengan domain atau disiplin, 2) kapasitas dengan proses komponen dan sebaiknya tidak disamakan dengan gaya pembelajaran, gaya kognitif, atau gaya kerja, 3) sepenuhnya berdasarkan bukti empiris yang dapat direvisi atau ditambahkan berdasarkan penemuan empiris baru. ${ }^{56}$ Yang penting Multiple Intelligence sama pentingnya dan banyak orang menguasai tiga atau empat, tetapi tidak pasti karena selalu ada ruang untuk perkembangan. Pada ayat-ayat al-Quran di dalamnya pun terdapat kata-kata yang memiliki makna kecerdasan atau dekat dengan makna kecerdasan. Berikut ini merupakan Kecerdasan anak yang didasarkan pada teori Multiple Intellegences diantaranya adalah:

\section{Kecerdasan Pribadi / Kecerdasan Intrapersonal}

${ }^{56}$ Howard Gardner, Reflections on Multiple Intelligences, Myths and Messages,"PhilDelta Kappa, November 1995. Hlm 200-203, 206-209. 
ISTIGHNA, Vol. 1, No 2, Juli 2018 P-ISSN 1979-2824

Homepage: http://e-journal.stit-islamic-village.ac.id/index.php/istighna

Juli Astuti

Rahasia Multiple Intelligence Pada Anak

Karakteristik kecerdasan pribadi / intrapersonal pada diri anak adalah berpikir dalam keheningan, suka menyendiri, berorientasi pada tujuan, independen dan bertekun. Kecerdasan intrapersonal berkaitan dengan aspek dalam diri seseorang, seperti perasaan hidup, rentang emosi, kemampuan untuk membedakan emosi-emosi, menandainya dan menggunakannya untuk memahami dan membimbing tingkah laku sendiri (Gardner, 1993). Kecerdasan pribadi ini pun banyak dijelaskan di dalam al-Quran, seperti pada surat adz-Dzariyst ayat 21 beikut: "Dan (juga) pada dirimu sendiri, maka apakah kamu tiada memperhatikan" (Q.S. adz-Dzariyat/52: 21). Anak yang cenderung memiliki kecerdasan intrapersonal umunnya suka mencermati penciptaan dirinya, Allah swt menciptakan bentuk tubuh manusia yang sangat sempurna, seperti yang telah diungkapkan di atas, juga kemampuan mencermati dan menganalisa prilaku dirinya. Bekerja sendiri ketimbang dengan orang lain, suka menetapkan serta meraih sasaran-sasaran sendiri, menjunjung tinggi rasa percaya diri meski tidak popular, tidak terlalu mengkhawatirkan kata-kata orang. Anak-anak dengan kecerdasan intrapersonal yang baik terlihat lebih mandiri, memiliki kemauan yang keras, penuh percaya diri, memiliki tujuan-tujuan tertentu (Schmidt, 2002).

Stimulus untuk anak: Menjalin komunikasi yang baik dengan anak-anak, Pengakuan akan keberbedaan gaya belajar anak mutlak di ciptakan. Model permainan yang memperkenalakan berbagai emosi dan perasaan. Memberikan sikap positif, pujian yang tulus, sikap tidak mencela, menghargai pilihan anak, kemauan mendengarkan cerita dan ide-ide anak.

Peralatan yang orang tua dapat gunakan untuk membantu menstimulasi perkembangan kepintaran anak dalam kecerdasan Intrapersonal yaitu: ruangan pribadi untuk menyendiri, bahan untuk hobi khusus yang disukainya, materi dan mainan untuk drama peran, buku diary.

\section{Kecerdasan Linguistik / Kecerdasan bahasa}

Model kecerdasan ini melibatkan kemampuan berbahasa, berpikir melalui kata-kata, menggunakan kata, untuk pembelajaran. Seorang anak yang memiliki kecerdasan linguistik memiliki kemampuan berbicara yang baik dan efektif. Ia juga cenderung dapat mempengaruhi orang lain melalui kata katanya, mungkin 
ISTIGHNA, Vol. 1, No 2, Juli 2018 P-ISSN 1979-2824

Homepage: http://e-journal.stit-islamic-village.ac.id/index.php/istighna

Juli Astuti

Rahasia Multiple Intelligence Pada Anak

pula ia suka dan pandai bercerita serta melucu dengan kata-kata. Dalam Islam dikenal istilah "Iqra" yang mengarahkan anak tidak hanya bisa baca-tulis bahasa sehari-hari, melainkan juga dididik untuk bisa membaca, mengenal, dan menghafal ayat-ayat al-Quran.

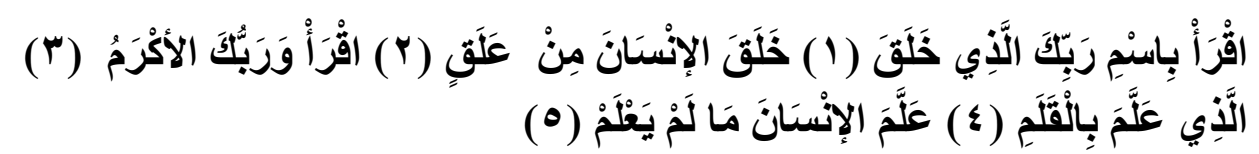

Artinya : 1) Bacalah dengan (menyebut) nama Rabbmu Yang menciptakan, 2) Dia telah menciptakan manusia dengan segumpal darah 3) Bacalah, dan Rabbmulah Yang Paling Pemurah, 4) Yang mengajar (manusia) dengan perantaraan kalam 5) Dia mengajarkan kepada manusia apa yang tidak diketahuinya.(Qs.Al-‘Alaq 1-5).

Allah Swt mengawali permulaan turunnya al-Qur'an dengan ayat yang memerintahkan Nabi Saw untuk "membaca", walaupun pada saat itu keadaan beliau adalah orang yang umiy (tidak mengenal baca-tulis). Perintah membaca tersebut bukan hanya untuk hal yang tersurat tapi juga untuk hal yang tersirat. Bukan hanya baca ‘tulisan' tapi juga membaca kehidupan, membaca ciptaan Allah dan membaca keagungan Allah.

Selain itu kecerdasan verbal linguistik juga terdapat dalam QS. Ar Rahman: 1- 4: Artinya: (Allah) Yang Maha Pengasih, Yang telah mengajarkan al-Qur'an, Dia menciptakan manusia, mengajarnya pandai berbicara

Ayat di atas merupakan bukti bahwa Allah telah mengajarkan kepada manusia al-Qur'an dan mengajarkannya (Nabi Muhammad Saw) pandai berbicara sehingga dapat menyampaikan ayat-ayat al-Qur'an kepada umatnya. Dari ayat ini dapat dijadikan dasar pengajaran linguistik verbal. ${ }^{57}$ Anak yang cenderung memiliki kecerdasan linguistik umumnya senang mendengarkan cerita, senang bercerita, senang bermain peran, serta permainan yang berhubungan dengan katakata. Maka, kisah-kisah tauladan Nabi perlu dikenalkan kepada anak sejak dini. Tiga hal yang diperintahkan Nabi untuk diajarkan kepada anak-anak kita terkait berbagai kecerdasan intelektual, termasuk kecerdasan linguistik ini. "Didiklah 2012,24 .

${ }^{57}$ Muhammad Yaumi, Pembelajaran Berbasis Multiple Intelligences, Jakarta: Dian Rakyat, 
ISTIGHNA, Vol. 1, No 2, Juli 2018 P-ISSN 1979-2824

Homepage: http://e-journal.stit-islamic-village.ac.id/index.php/istighna

Juli Astuti

Rahasia Multiple Intelligence Pada Anak

anak-anakmu pada tiga perkara: mencintai Nabi-mu, mencintai ahli baitnya, dan membaca al-Qur'an." (H.R. Ath-Thabrani).

Stimulus untuk anak: Mengajak mereka berbicara, menyediakan banyak buku, rekaman, serta menciptakan peluang mereka untuk menulis. Ajaklah anak untuk bermain tebak-tebakan, misalnya tentang ciri-ciri binatang. "Ada binatang, suaranya guk-guk, warna bulunya putih. Kamu sayang sekali padanya. Binatang apa itu, ya? Dan mintalah si anak untuk bercerita tentang apa saja yang sudah dia lakukan hari ini.

Peralatan yang orang tua dapat gunakan untuk membantu menstimulasi perkembangan kepintaran anak dalam kecerdasan linguistik adalah: buku anakanak, majalah untuk aktivitas memotong, perekam suara untuk merekam suara mereka, huruf alfabet dengan ukuran dan bentuk yang berbeda, perlengkapan menggambar dan kertas untuk menulis, stampel alfabet dan susun bangun kata.

\section{Kecerdasan Moral / Kecerdasan Interpersonal}

Kemampuan anak untuk melakukan hubungan dan komunikasi yang baik dengan orang lain, memahami orang lain, berproses melalui interaksi, berimpati, humor, mudah bersosialisasi. Anak-anak yang memiliki kecerdasan interpersonal cenderung memahami perasaan orang lain, mereka sering jadi pemimpin, dapat bernegosiasi kepada orang lain dan pandai mengkomunikasikan keinginannya pada orang lain dan berempati pada orang lain. Ayat-ayat al-Quran yang di dalamnya menyinggung orang-orang yang memiliki akal (kecerdasan) yang terkait dengan moral seperti surat (An-Nahl 16: 90)

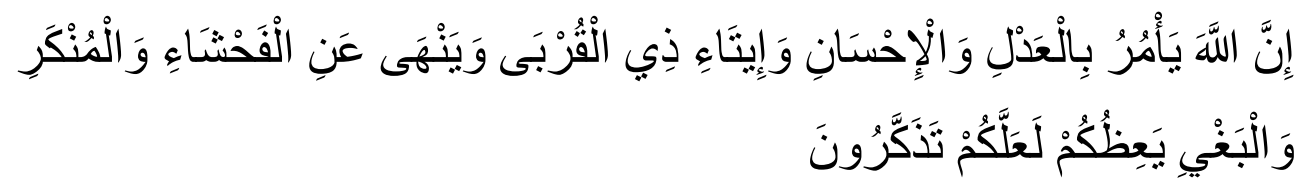

Artinya: Sesungguhnya Allah menyuruh kamu berlaku adil dan berbuat kebijakan, memberi kepada kamu kerabat, dan Allah melarang dari perbuatan keji, kemungkaran dan permusuhan. Dia memberi pengajaran kepadamu agar kamu dapat mengambil pelajaran. Juga dalam ayat berikut, Surat al-Qalam: 5:

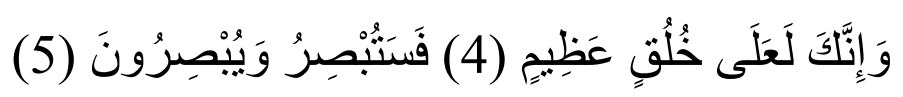


ISTIGHNA, Vol. 1, No 2, Juli 2018 P-ISSN 1979-2824

Homepage: http://e-journal.stit-islamic-village.ac.id/index.php/istighna

Juli Astuti

Rahasia Multiple Intelligence Pada Anak

Artinya: "Dan Sesungguhnya kamu benar-benar berbudi pekerti yang agung. Maka kelak kamu akan melihat, dan mereka (orang-orang kafir) pun akan melihat"(Q.S. Al-Qalam/68: 4-5)

Kecerdasan interpersonal menunjukkan kemampuan seseorang anak untuk peka terhadap perasaan orang lain. Mereka cenderung untuk memahami dan berinteraksi dengan orang lain sehingga mudah bersosialisasi / beradabtasi dengan lingkungan di sekelilingnya.

Kecerdasan interpersonal juga tertera dalam firman Allah surat al-Maa'uun ayat 1-3 Artinya: Tahukah kamu (orang) yang mendustakan agama? Maka itulah orang yang menghardik anak yatim, dan tidak mendorong memberi makan orang miskin (QS Al-Maa'uun: 1-3) Dalam QS. Al-Maa'uun ayat 1-3 dijelaskan bahwa orang yang termasuk mendustakan agama adalah orang-orang yang menghardik anak yatim dan tidak menganjurkan memberi makan orang miskin. Dari ayat ini dapat dipetik pelajaran bahwa kasih sayang dan saling tolong menolong dalam agama Islam sangat dianjurkan sesuai dengan karakteristik kecerdasan interpersonal.

Stimulus untuk anak: Mempraktikan keterampilan berkomunikasi yang baik verbal maupun non verbal dengan cara bermain peran. Bereksperimen dengan peran-peran dirumah, sekolah dan komunitas. Merespon perasaan menunggu giliran dan berbagi materi dan pengalaman.

Peralatan yang orang tua dapat gunakan untuk membantu menstimulasi perkembangan kepintaran anak dalam kecerdasan Interpersonal yaitu kostum untuk permainan peran (make-believe), rumah boneka, segala jenis boneka dan boneka hewan, figur miniatur, wayang/boneka dan teater boneka/wayang, permainan papan (board games).

\section{Kecerdasan Naturalis}

Karakteristik kecerdasan naturalis yang ada pada anak yaitu: perlu pertahanan alami, kekuatan dalam kategorisasi alami atau dunia urban. Kemampuan seseorang anak ini biasanya menyayangi binatang dan tumbuhan. Kemampuan untuk mengerti flora dan fauna dengan baik, menikmati alam, mengenal tanaman dan binatang dengan baik. Pengembangan intelegensi 
ISTIGHNA, Vol. 1, No 2, Juli 2018 P-ISSN 1979-2824

Homepage: http://e-journal.stit-islamic-village.ac.id/index.php/istighna

Juli Astuti

Rahasia Multiple Intelligence Pada Anak

lingkungan anak-anak dapat diasah dengan mengajak menanam atau berkebun, mengamati pertumbuhan tanaman, beternak dan sebagainya. Anak yang memiliki intelegensi lingkungan/naturalis umumnya suka mengamati, mengenali, berinteraksi, dan peduli dengan objek alam, tanaman atau hewan, antusias akan lingkungan alam dan lingkungan manusia, senang memelihara tanaman, hewan, senang mempelajari siklus kehidupan flora dan fauna, dan senang melakukan aktivitas outdoor seperti jalan-jalan.

Dalam surah an-Naml: 6-9 Artinya: 6) Dan kamu memperoleh pandangan yang indah padanya, ketika kamu membawanya kembali ke kandang dan ketika kamu melepaskannya ke tempat penggembalaan. 7) Dan ia memikul bebanbebanmu ke suatu negeri yang kamu tidak sanggup sampai kepadanya, melainkan dengan kesukaran-kesukaran (yang memayahkan) diri. Sesungguhnya Tuhanmu benar-benar Maha Pengasih lagi Maha Penyayang. 8) dan (Dia telah menciptakan) kuda, bagal dan keledai, agar kamu menungganginya dan (menjadikannya) perhiasan. Dan Allah menciptakan apa yang kamu tidak mengetahuinya. 9) Dan hak bagi Allah (menerangkan) jalan yang lurus, dan di antara jalan-jalan ada yang bengkok. Dan jikalau Dia menghendaki, tentulah Dia memimpin kamu semuanya (kepada jalan yang benar).

Stimulus untuk anak: Mengajak anak-anak untuk menikmati dan mengamati alam terbuka, pembelajaran dapat dilakukan di luar kelas, membiasakan untuk memelihara hewan, menyiram tanaman, menanam biji-bijian dalam media yang mudah dibawa dan mengamati pertumbuhannya. Menciptakan program pembelajaran yang berkaitan dengan alam.

Profesi: dokter hewan, ahli botani, ahli biologi, pendaki gunung, pengurus organisasi lingkungan hidup, kolektor fauna/flora, penjaga museum zoologi / botani dan kebun binatang, dan sebagainya.

\section{Kecerdasan Logic Math}

Karakteristik kecerdasan Logic Math ini biasanya anak dapat memproses secara analistis, mengkakulasi, dan mengukur. Kecerdasan logic math ini berkaitan dengan kemampuan mengelolah angka dan tau kemahiran menggunakan logika. Biasanya anak ini tertarik dengan memanipulasi lingkungan serta 
ISTIGHNA, Vol. 1, No 2, Juli 2018 P-ISSN 1979-2824

Homepage: http://e-journal.stit-islamic-village.ac.id/index.php/istighna

Juli Astuti

Rahasia Multiple Intelligence Pada Anak

cenderung suka menerapkan strategi coba-ralat. Mereka suka menduga duga sesuatu dan rasa ingin tahunya besar tentang peristiwa di sekitarnya. Di dalam pendidikan Islam pun telah mengajarkan anak untuk memiliki kecerdasan logis matematis atau cerdas angka akan berfikir secara numerik atau dalam konteks pola serta urutan logis, atau dalam bentuk-bentuk cara berfikir logis yang lain. Allah berfirman: Surat al-Angkabut: 43.

Artinya: Dan perumpamaan-perumpamaan ini Kami buatkan untuk manusia; dan tiada yang memahaminya kecuali orang-orang yang berilmu. (QS Al-Angkabut: 43) ${ }^{58}$

Dari ayat di atas kita akan memahami ayat-ayat Allah dengan berfikir logis. Didalam al-Qur'an banyak perumpamaan-perumpamaan yang hanya orang-orang berilmu saja yang akan memahaminya. Untuk memahami perumpamaan tersebut harus dengan berfikir logis.

Stimulus untuk anak: Memberikan anak materi materi konkret yang dapat dijadikan bahan percobaan, berinteraksi positif yang mampu memuaskan rasa tahu anak dengan memberikan penjelasan yang logis. Memberikan permainan yang membutuhkan kemampuan memecahkan masalah permainan yang menggunakan kemampuan membandingkan dan mengajak anak untuk ketempat tempat yang dapat mendorong pemikiran ilmiah.

Peralatan yang disiapkan oleh orang tua untuk anak yaitu: computer, maze, angka-angka, mengajak ke museum.

\section{Kecerdasan Spacial / visual}

Kecerdasan spasial ini biasanya anak memiliki kemampuan karakteristik menggunakan model mental, berpikir secara tiga dimensi, menggambarkan bagaimana memperoleh tempat atau memecahkan masalah. Kecerdasan yang melibatkan kepekaan mengobservasi dan kemampuan berpikir dalam gambar. Menurut Howard Gardner menyimpulkan Kecerdasan Visual, sebagaimana dikutip oleh Agus Efendi, sebagai berikut: "Bahwa pandangan kecerdasan spasial ini, kita telah menemukan bentuk kedua dari kecerdasan yang terlibat dengan objek. Berbeda dengan pengetahuan logis-matematis yang mencakup jalan

\footnotetext{
${ }^{58}$ Ibid, 799
} 
ISTIGHNA, Vol. 1, No 2, Juli 2018 P-ISSN 1979-2824

Homepage: http://e-journal.stit-islamic-village.ac.id/index.php/istighna

Juli Astuti

Rahasia Multiple Intelligence Pada Anak

perkembangannya dengan meningkatkan abstraksi, kecerdasan spasial tetap terkait-terikat pada dunia nyata secara fundamental, terkait dengan dunia objek, dan lokasinya berada di dunia. ${ }^{59}$ Kecerdasan ini memungkinkan anak membayangkan bentuk-bentuk geometri atau tiga dimensi dengan lebih mudah. Biasanya, anak menyukai kegiatan bermain puzzle, menggambar, bermain balok, mencari jalan paling tepat, serta menghabiskan waktu luang untuk melamun.

Dalam al-Quran yang menyatakan kecerdasan visual / special adalah surat Qaf ayat 7 dan 8 : "Dan juga (keadaan) bumi ini, (bagaimana) Kami bentangkan Dia sebagai hamparan, dan Kami letakkan padanya gunung-ganang yang terdiri kukuh, serta Kami tumbuhkan padanya pelbagai jenis tanaman yang indah subur? (Kami adakan semuanya itu) untuk menjadi perhatian dan peringatan, (yang menunjukkan jalan kebenaran), kepada tiap-tiap seorang hamba Allah Yang Maha kembali kepadanya (dengan taat dan berbakti).(Q.S. Qaf/50: 7-8). Dalam ayat tersebut memerintahkan kapada manusia agar melihat dan merenungkan keindahan jagad raya ciptaan Allah.

Stimulasi: Ajak anak memilih sebuah gambar, misalnya dari majalah lama, Gunting secara acak, lalu minta dia menyusunnya sehingga menjadi gambar yang utuh kembali. Biarkan anak bereksplorasi saat ia menggambar. Gunakan kapur, plastisin, cat air atau krayon dengan berbagai alat bantu seperti sikat, gunting, tangan dan kaki, bahkan sayuran untuk menggambar atau mencetak gambar. Ajak anak berdiskusi tentang hasil karyanya, termasuk tekstur, warna dan ukurannya.

\section{Kecerdasan Kinestetik}

Inteligensi kinestetik tubuh, yaitu kemampuan yang berhubungan dengan gerakan tubuh termasuk gerakan motoric otak yang mengendalikan tubuh seperti kemampuan untuk mengendalikan dan menggunakan badan dengan mudah dan cekatan. Karakteristiknya antara lain: Senang menari, acting, pandai dan aktif dalam olahraga tertentu, mudah berekspresi dengan tubuh, mampu memainkan mimic, koordinasi dan fleksibilitas tubuh tinggi, senang dan efektif berpikir sambil berjalan, berlari, dan berolah raga, pandai merakit sesuatu menjadi suatu

${ }^{59}$ Agus Efendi, Revolusi Kecerdasan Abad 21, (Bandung, Alfabeta, 2005), Cet. I, h.177 
ISTIGHNA, Vol. 1, No 2, Juli 2018 P-ISSN 1979-2824

Homepage: http://e-journal.stit-islamic-village.ac.id/index.php/istighna

Juli Astuti

Rahasia Multiple Intelligence Pada Anak

produk, senang bergerak atau tidak bisa diam dalam waktu yang lama dan Senang kegiatan di luar rumah.

Al-Quran memberikan petunjuk kepada manusia untuk memiliki kecerdasan untuk memelihara badannya/ tubuhnya, sehingga terhindar dari hal-hal yang membahayakan bagi tubuhnya. Seperti dalam surat al-Baqarah ayat 219 : "Mereka bertanya tentang khamar dan judi. Katakanlah: "Pada keduanya itu terdapat dosa besar dan beberapa manfaat bagi manusia, tetapi dosa keduanya lebih besar dari pada manfaatnya". Dan mereka bertanya kepadamu: apa yang mereka nafkahkan?. Katakanlah: "Yang lebih dari keperluan". Demikianlah Allah menerangkan ayat-ayat-Nya kepadamu supaya kamu berfikir"

Stimulus: ajak anak untuk menari dengan melakukan gerakan gerakan yang diiringi oleh irama dan saat menari dituntut untuk bisa memperhatikan dan meniru gerakan dan memadankan dengan music. Bukan hanya menari saja namun ajaklah anak untuk bermain peran, drama dan olah raga.

\section{Kecerdasan Musical}

Berbagai studi membuktikan bahwa kecerdasan music memiliki keterkaitan yang erat dengan berbagai kecerdasan lainnya. Meskipun orang dengan kecerdasan music menonjol belum tentu akan menjadi seorang composer yang hebat, namun kecerdasan ini perlu diasah untuk menjaga keseimbangan perkembangan anak secara umum.

Kecerdasan musik adalah kemampuan anak untuk menikmati, mengamati, membedakan, mengarang, membentuk dan mengekspresikan bentuk-bentuk musik. Kecerdasan ini meliputi kepekaan terhadap ritme, melodi, dan timbredari musik yang didengar.

Dalam al-Quran surah al-Isra' ayat 107 dan 108 Allah Swt berfirman, yang artinya: "Sesungguhnya orang-orang yang diberi pengetahuan sebelumnya apabila al-Quran dibacakan kepada mereka, mereka menyungkur atas muka mereka sambil bersujud. Mereka berkata, 'Maha Suci Tuhan kami, sesungguhnya janji Tuhan kami pasti dipenuhi.' Ayat ini menunjukkan bahwa orang-orang yang memahami kandungan al-Quran serta sisi-sisi keindahannya, pasti akan bersujud dan memuji keagungan Allah Swt. Ketika ayat-ayat Ilahi dibacakan dengan suara 
ISTIGHNA, Vol. 1, No 2, Juli 2018 P-ISSN 1979-2824

Homepage: http://e-journal.stit-islamic-village.ac.id/index.php/istighna

Juli Astuti

Rahasia Multiple Intelligence Pada Anak

yang indah dan irama yang menarik, suara al-Quran akan mampu meredakan api kemarahan di dalam dada dan menggantinya dengan rasa cinta dan kasih sayang.

Stimulus: ajaklah anak mendengarkan lagu, bersenandung dan bermain music. kegiatan bersenandung pada anak biasanya muncul saat mereka mengerjakan sesuatu dengan asyik, misalnya saat mewarnai gambar, mengamati binatang peliharaan sambil mendengarkan music yang berdendang.

\section{Kecerdasan Spiritual / Eksistensialis}

Kecedasan Spiritual (Spiritual Quotion) adalah kecerdasan untuk menghadapi dan memecahkan persoalan makna dan nilai, yaitu kecerdasan untuk menempatkan prilaku dan hidup kita dalam konteks makna yang lebih luas dan kaya, kecerdasan untuk menilai bahwa tindakan atau jalan hidup seseorang lebih bermakna dibandingkan dengan yang lain. Kecerdasan yang menfasilitasi suatu dialog antara akal dan emosi, antara pikiran dan tubuh, menyediakan titik tumpu bagi pertumbuhan dan perubahan, menyediakan pusat pemberi makna yang aktif dan menyatu bagi diri. ${ }^{60}$ Kecerdasan ini akan membentuk jiwa dan pribadi yang berakhlak mulia dan bermanfaat bagi dirinya, keluarga, masyarakat dan negaranya. Anak yang memiliki kecerdasan ini cenderung memiliki kesadaran akan hakikat sesuatu. Al-Qur'an berbicara:

"Wahai orang-orang yang beriman bertakwalah kepada Allah dan hendaklah setiap orang memperhatikan apa yang telah diperbuatnya untuk hari esok (akhirat) dan bertakwalah kepada Allah sungguh Allah Maha teliti atas apa yang kamu kerjakan.” (Al-Hasr/59: 18)

Kecerdasan spiritual merupakan goal dari keberhasilan pengembangan semua kecerdasan. Gabungan dari semua fungsi otak sehingga menghasilkan manusia yang bermanfaat bagi diri sendiri, orang lain, alam dan lingkungan.

Dalam hal ini Gardner menjeaskan: Manusia cenderung merenungkan pertanyaan yang paling fundamental tentang keberadaan Mengapa kita hidup? Mengapa kita mati? Dari mana kita datang? Apa yang akan terjadi pada kita? Apakah cinta itu? Mengapa kita berperang? Pertanyaan-pertanyaan itu terkadang

${ }^{60}$ Agus Efendi, Revolusi Kecerdasan Abad 21, h. 216. 
ISTIGHNA, Vol. 1, No 2, Juli 2018 P-ISSN 1979-2824

Homepage: http://e-journal.stit-islamic-village.ac.id/index.php/istighna

Juli Astuti

Rahasia Multiple Intelligence Pada Anak

melebihi persepsi, semua berhubungan dengan persoalan-persoalan yang terlalu besar atau terlalu kecil untuk dirasakan oleh kelima system indera utama kita. ${ }^{61}$

Kecerdasan eksistensial merupakan kemampuan untuk mengakses suatu jalan yang bermakna. ${ }^{62}$ yakni kecerdasan yang berkenaan dengan hati dan kepedulian antar sesama manusia, makhluk lain dan alam sekitar berdasarkan keyakinan akan adanya Tuhan Yang Maha Esa.

Stimulus untuk anak: Melalui teladan dalam bentuk nyata yang diwujudkan dalam perilaku baik lisan, tulisan dan perbuatan dalam pendekatan sentra. Mengadakan kegiatan bercerita yang diakhiri pertanyaan-pertanyaan yang menggugah kesadaran seperti: "Bagaimana jika kita tidak memiliki ibu?, "Bagaimana jika tidak ada matahari ?"

\section{Kecerdasan Emosional}

Kecerdasan Emosional adalah kemampuan mengenali perasaan diri kita sendiri dan perasaan orang lain, kamampuan memotivasi diri sendiri, dan kemampuan mengelola emosi dengan baik pada diri sendiri dan dalam hubungannya dengan orang lain. Emosi merupakan salah satu dari trilogi mental yang terdiri dari; kognisi, emosi, dan motivasi. Anak-anak dengan kecerdasan emosional yang tinggi dapat sangat ramah, kooperatif, optimis dan lebih dapat memecahkan masalah. Mereka cenderung lebih baik perilakunya dan memiliki prestasi akademik yang lebih tinggi. Maka dalam pengertian Islam, dimensi kesadaran diri sesungguhnya dikenal sebagai proses muraqabah dan muhasabah Hal ini didasarkan pada Q.S. An-Nisaa (4) : 1 yang berbunyi: "Sesungguhnya Allah selalu menjaga dan mengawasi kamu." Rasulullah bersabda bahwa hendaknya umat muslim senantiasa mengawasi amal perbuatan diri sebagaimana hadits Abu Nu'aim berikut: "Beribadahlah kepada Allah seolah-olah engkau melihat-Nya, sekalipun kamu tidak melihat-Nya tetapi Dia melihatmu." Dan Koreksi diri ini didasarkan pada ayat berikut ini: "Hai orang-orang yang beriman,

61 Howard Gardner,Multiple Intellegences, Memaksimalkan Potensi dan Kecerdasan Individu dari Masa Kanak-Kanak Hingga Dewasa, (Indonesia,Daras books 2013 )h. 31

${ }^{62}$ Muhammad Yaumi dan Nurdin Ibrahim, Pembelajaran Berbasis kecerdasan jamak (Multiple Intelligences): Mengidentifikasi dan Mengembangkan Multi talenta Anak ( Jakarta;Prenada Media Group/Kencana 2013) h.23. 
ISTIGHNA, Vol. 1, No 2, Juli 2018 P-ISSN 1979-2824

Homepage: http://e-journal.stit-islamic-village.ac.id/index.php/istighna

Juli Astuti

Rahasia Multiple Intelligence Pada Anak

bertakwalah kepada Allah dan hendaklah setiap diri memperhatikan apa yang telah diperbuatnya untuk hari esok (akhirat), dan bertakwalah kepada Allah, sesungguhnya Allah Maha Mengetahui apa yang kamu kerjakan.” (Q.S. Al-Hasyr [59] : 18).

Stimulus untuk anak: Terima emosi anak dan berikan tanggapan yang emosional, ajak anak untuk berbicara mengenai perasaannya, berilah pelajaran mengenali perasaan orang lain, misalnya ketika terlihat ia sering mengepalkan tangan, mungkin itu tanda ia sedang marah, mengajarkan menenangkan diri.

\section{Pokok-pokok Pikiran Munif Chatib tentang Multiple Intelligences}

Ada Lima Bingkisan Peserta didik dalam Pembelajaran Berbasis Multiple Intelligences. ${ }^{63}$

Seorang guru harus mampu membuka lima bingkisan peserta didik, sebelum memasuki pembelajaran berbasis multiple intelligences. Dan lima bingkisan tersebut, adalah: bintang, samudra, harta karun, penyelam dan bakat.

1. Bintang: Memandang setiap anak adalah bintang kelas / dilahirkan adalah juara. Bintang yang sinarnya mampu menerangi dunia. Bagaimanapun kondisi anak, mereka adalah bintang dan juara. Adapun kuncinya adalah sebagai seorang guru sebelum memasuki kelas, maka seorang guru tersebut harus menyalakan tombol “on”dalam benak guru, yang menganggap bahwa setiap peserta didik adalah bintang, maka peserta didik akan menjadi bintang. (Munif Chatib, 2012: 58)

2. Samudra: memiliki kemampuan seluas samudra: kemampuan kognitif yang menghasilkan daya pikir positif, kemampuan psikomotorik yang menghasilkan karya bermanfaat dan penampilan yang dahsyat, serta kemampuan afektif yang menghasilkan nilai dan karakter yang manusiawi sesuai fitrahnya. Munif Chatib dalam buku yang berjudul "Orangtuanya manusia" (2012: 87) menjelaskan bahwa kemampuan anak kita seluas samudra. Yang artinya, pasti banyak potensi yang terpendam di dalam dirinya, seperti halnya samudra dengan

${ }^{63}$ Munif Chotib, Sekolahnya Manusia: Sekolah berbasis Multiple Intellegences Di Indonesia,( Jakarta, Mizan 2012) hal 58 
ISTIGHNA, Vol. 1, No 2, Juli 2018 P-ISSN 1979-2824

Homepage: http://e-journal.stit-islamic-village.ac.id/index.php/istighna

Juli Astuti

Rahasia Multiple Intelligence Pada Anak

berbagai potensi kekayaan alamnya. Berbagai potensi terpendam merupakan harta karun orang tuanya yang ada dalam diri anak, yaitu kecerdasan majemuk atau dinamakan pula multiple intelligences. ${ }^{64}$

3. Harta Karun: setiap anak memiliki variasi potensi kecerdasan masingmasing. Ada yang punya satu kecerdasan yang dominan, sedangkan yang lainnya rendah. Ada yang memiliki dua, tiga, bahkan semua kecerdasannya dominan. Namun, tidak ada manusia yang bodoh, terutama jika stimulus yang diberikan lingkungan tepat. Oleh sebab itu galilah potensi anak didik sebagaimana seperti harta karun.

4. Penyelam: Discovering ability, kembangkan kemampuan dan kubur ketidakmampuan anak. Discovering ability adalah aktivitas guru untuk menjelajahi kemampuan peserta didik pada saat hasil tes peserta didik di bawah standar ketuntasan. Discovering abilityjuga dapat diartikan meminta peserta didik untuk menjawab soal yang sama dengan cara yang lain. Apabila discovering ability ini tidak berhasil, maka baru dilakukan remedial test (tes pengulangan). Banyak sekali guru yang langsung melompat dengan memberikan remedial test kepada peserta didik dengan nilai dibawah standar tanpa melalui fase discovering ability. (Munif Chatib, 2012: 158)

5. Bakat: Temukan bakat pada diri anak. Bakat pada setiap anak itu berbeda beda.

Berdasarkan lima bingkisan di atas tadi, maka dapat disimpulkan bahwa kecerdasan tidak terkait dengan kondisi fisik, kondisi brain, dan hasil tes standar (soal tertutup). Akan tetapi, terkait dengan: 1) Discovering Ability (anak mampu menemukan, mencari, proses), 2) Right Place (tempat yang tepat, diberi wadah untuk menyalurkan), dan 3) Benefiditas (mempunyai manfaat).

\section{Faktor-faktor yang mempengaruhi Inteligensi}

Ada beberapa faktor yang mempengaruhi pembentukan atau perkembangan inteligensi seseorang, yaitu:

\footnotetext{
${ }^{64}$ Munif Chotif, Orang tuanya manusia, ( Jakarta, Mizan; 2012)hlm 87
} 
ISTIGHNA, Vol. 1, No 2, Juli 2018 P-ISSN 1979-2824

Homepage: http://e-journal.stit-islamic-village.ac.id/index.php/istighna

Juli Astuti

Rahasia Multiple Intelligence Pada Anak

1. Faktor Pembawaan adalah kesanggupan/potensi yang dibawa sejak lahir yang merupakan bahan dasar untuk perkembangan. Setiap anak lahir dengan membawa potensi inteligensinya masing-masing, dan perkembangan inteligensi si anak akan dipengaruhi oleh kondisi inteligensi bawaannya masing-masing.

2. Faktor Kematangan adalah kesiapan suatu fungsi atau potensi untuk dikembangkan. Perkembangan inteligensi akan berlangsung dengan baik apabila fungsi/potensi inteligensi secara fisik atau psikologis sudah ada kematangan. Tanpa adanya faktor kematangan tersebut perkembangan inteligensi tidak akan terjadi.

3. Faktor Pembentukan adalah segala faktor luar yang akan mempengaruhi perkembangan Inteligensi. Faktor luar yang bersifat lebih efisien dan efektif pengaruhnya dalam pembentukan/perkembangan inteligensi ialah faktor pendidikan yang dilaksanakan disekolah. faktor luar lainnya yang dapat mempengaruhi secara tidak sengaja dan kurang efisien ialah pengaruh lingkungan/alam sekitar.

4. Faktor Minat adalah sikap senang kepada sesuatu hal Minat ini akan berfungsi sebagai pendorong orang untuk berbuat/berusaha dalam mencapai sesuatu tujuan. Minat ini sebagai faktor psikologis akan mempengaruhi proses pembentukan atau perkembangan.

5. Faktor Kebebasan adalah kondisi psikologis yang akan mempengaruhi sikap, performance atau aktifitas seseorang dalam berbuat atau mencapai tujuan atau dalam mewujudkan dirinya. Orang yang mempunyai kebebasan tidak merasa ada beban/tekanan untuk berbuat/mencapai sesuatu, ia dapat dengan bebas memilih/menentukan kebutuhan, cara atau tujuan yang sesuai dengan apa yang diminatinya. ${ }^{65}$

Semua faktor tersebut diatas saling berhubungan satu sama lain. Untuk menentukan Inteligensi atau tidaknya seorang anak, kita tidak dapat hanya berpedoman kepada salah satu faktor tersebut diatas. Inteligensi adalah faktor

${ }^{65}$ Alisuf Sabri, Psikologi Pendidikan Berdasarkan Kurikulum Nasional, (Jakarta: Pedoman Ilmu Jaya, 2007), hlm.123-124 
ISTIGHNA, Vol. 1, No 2, Juli 2018 P-ISSN 1979-2824

Homepage: http://e-journal.stit-islamic-village.ac.id/index.php/istighna

Juli Astuti

Rahasia Multiple Intelligence Pada Anak

total. Keseluruhan pribadi turut serta menentukan dalam perbuatan inteligensi seseorang. ${ }^{66}$

\section{E. Upaya yang perlu dilakukan pendidik dan orang tua}

Adapun upaya yang harus dilakukan oleh pendidik dan orang tua terhadap kecerdasan majemuk (Multiple Intelligences) sebagai berikut:

1. Memahami adanya perbedaan dan keunikan setiap anak Setiap anak memiliki keunikan atau kekahasan masing-masing. Anak lahir dengan kelebihan yang perlu digali dan diasah dengan pendampingan orang tua.

2. Tidak membandingkan karena meyakini bahwa setiap anak memiliki petensi atau kelebihan masing-masing. Membandingkan anak hanya akan melukai harga dirinya. Lebih baik berikan dorongan daripada membandingkan.

3. Mengamati kebiasaan dan kecenderungan minat anak melalui kegiatan yang dilakukannya. Kecenderungan anak memiliki pada suatu kegaitan dapat memberikan gambaran tentang minatnya. Oleh karena itu pengamatan yang berkesiambungan saangata diperlukan.

4. Menemukan kelebihan anak. Asah kelebihannya agar menutupi keterbatasan yang dimiliki. Dengan fokus pada keterampilan atau kecerdaasan memungkinkan anak meiliki nkeahlian yang spesifik.

5. Membantu anak mengoptimalkan dengan memberikan stimulasi melalui berbagai kegiatan. Stimulasi adalah kegiatan merangsang kemampuan dasar anak yang datangnya di luar individu anak agar anak tumbuh dan berkembang secara optimal. Setiap anak perlu mendapat stimulasi rutin sedini mungkin dan terus-menerus pada setiap kesempatan. Anak yang mendapatkan stimulasi lebih cepat berkembang dibandingkan dengan yang kurang atau tidak mendapat stimulasi. Kurangnya stimulasi dapat menyebabkan penyimpangan tumbuh kembang anak bahkan bisa menyebabkan gangguan yang menetap.

6. Memberikan dukungan emosional dan motivasi yang bermakna. Dukungan emosional dan motivasi lah satu merupakan bentuk penguatan

${ }^{66}$ Dalyono, Psikologi Pendidikan, (Jakarta: Rineka Cipta, 2010), hlm. 189. 
ISTIGHNA, Vol. 1, No 2, Juli 2018 P-ISSN 1979-2824

Homepage: http://e-journal.stit-islamic-village.ac.id/index.php/istighna

Juli Astuti

Rahasia Multiple Intelligence Pada Anak

yang diperlukan untuk memperkuat dan meningkatkan usaha atau prestasi yang telah dicapai. Dorongan dan motivasi meyakinkan diri anak bahwa dia diakui dan dihargai.

7. Memberikan penguatan agar anak mampu mempertahankan bahkan meningkatkan prestasinya.

\section{F. Penutup}

Dari uraian di atas jelaslah setiap individu memiliki potensi unik yang harus dikembangkan menjadi kompetensi. Manusia, pada dasarnya, memiliki beberapa jenis kecerdasan yang menonjol. Teori yang di berikan Howard Gardner tentang "Multiple Intellegences" meyatakan bahwa setiap anak memiliki satu atau lebih dari sepuluh kecerdasan yang ada. Sehingga setiap anak itu cerdas dan dapat menjadi bintang sesuai dengan kecerdasan yang dimiliki. Ada anak yang cerdas dalam kemampuan logika-matematika, ada pula yang cerdas dalam kemampuan musik, kinestetik, interpersonal, intrapersonal, linguistik, special, eksistensial, natural dan emosional. Penemuan Gardner tentang pelbagai intellegensi membuka cakrawala bagi kita dalam memandang kecerdasan dan tidak terkukung dalam paradigma lama tentang penilaian IQ. Dengan memahami siapa anak kita dan apa tujuan belajar, akan mendapatkan kebahagian yang hakiki.

\section{Daftar Pustaka}

Agus Efendi, Revolusi Kecerdasan Abad 21, (Bandung, Alfabeta, 2005), Cet. I

Alamsyah Said, Strategi Mengajar Multiple Intellegences, (Jakarta Prenadamedia Grup 2015)

Alisuf Sabri, Psikologi Pendidikan Berdasarkan Kurikulum Nasional, (Jakarta: Pedoman Ilmu Jaya, 2007)

Arief Rachman, "Genius Learning Strategy" dalam Adi W. Gunawan, Genius Learning Strategy: Petunjuk Praktis untuk Menerapkan Accelerated Learning, (Jakarta: PT. Gramedia Pustaka Utama, 2006)

Dalyono, Psikologi Pendidikan, (Jakarta: Rineka Cipta, 2010)

Eric Jensen, Memperkaya otak; Cara Memaksimalkan Potensi Setiap Pembelajar,(Jakarta; Indeks, 2008). 
ISTIGHNA, Vol. 1, No 2, Juli 2018 P-ISSN 1979-2824

Homepage: http://e-journal.stit-islamic-village.ac.id/index.php/istighna

Juli Astuti

Rahasia Multiple Intelligence Pada Anak

Fred luthans, Perilaku Organisasi edisi 10 (Jogyakarta copy right, 2006)

Howard Gardner, Multipel Intelligences ; Kecerdasan Majemuk Teori dan Praktek, penerjemah Alexandra sindoru, (Batam: Interaksara, 2003 )

Howard Gardner, Multiple Intelligences: Kecerdasan Majemuk Teori dan Praktek, penerjemah Alexander Sindoru, (Batam: Interaksara, 2003)

Howard Gardner,Multiple Intellegences, Memaksimalkan Potensi dan Kecerdasan Individu dari Masa Kanak-Kanak Hingga Dewasa, (Indonesia,Daras books 2013 )

http: //www.mitest.com/omultint.htm.

Muhammad Yaumi dan Nurdin Ibrahim, Pembelajaran Berbasis kecerdasan jamak (Multiple Intelligences): Mengidentifikasi dan Mengembangkan Multi talenta Anak ( Jakarta;Prenada Media Group/Kencana 2013) .

Munif Chatib, Sekolahnya Manusia Sekolah Berbasis Multiple Intelligences (Bandung: Kaifa, 2015)

Munif Chotif, Orang tuanya manusia, ( Jakarta, Mizan; 2012).

Paul Suparno, Teori Inteligensi ganda dan aplikasinya di sekolah, (Yogyakarta;Kanisus, 2004) cet.1

Syaikh Muhammad Nawawi bin Umar al Jawiy, Syarh Nashaihul 'Ibad, (Surabaya: Darul 'Abidin)

Tadkiroatun Musfiroh, Cerdas Melalui bermain (cara mengasah Multipel Intellegence anak), (Jakarta, Grasindo 2008). 